\title{
Analisis Perawat dalam Upaya Pencegahan
}

Hazard

\author{
Dea Kristin Sania Manik \\ Deakristin01@gmail.com
}

\section{Latar Belakang}

Terdapat berbagai macam teknik yang dapat digunakan untuk melakukan analisis risiko yang ada di tempat kerja, baik kualitatif, semi maupun kuantitatif. Teknik analisis ini sangat bermanfaat untuk penekanan tingkat risiko tersebut sehingga tingkat kecelakaan dan penyakit akibat kerja terkurangi. Salah satu teknik analisis yang dapat diterapkan yaitu analisis bahaya pekerjaan atau Job Hazard Analysis (JHA). Teknik ini fokus kepada hubungan antara pekerja, pekerjaan, alat kerja, dan lingkungan kerja. Melalui kegiatan ini dapat diambil langkah-langkah untuk menghilangkan dan mengurangi tingkat risiko dari bahaya di tempat kerja. (OSHA 3071, 2002).

Identifikasi Bahaya (Hazards Identification), Penilaian Risiko (Risk Assessment) dan Pengendalian Risiko (Risk Control) atau yang disingkat HIRARC merupakan suatu elemen pokok dalam sistem manajemen Keselamatan dan Kesehatan Kerja yang berkaitan dengan upaya pencegahan dan pengendalian bahaya. Keseluruhan proses dari HIRARC yang disebut juga dengan manajemen risiko (risk management), kemudian akan menghasilkan dokumen HIRARC yang sangat berguna untuk mencegah terjadinya kecelakaan kerja.

Kata Kunci : Pengetahuan, Perawat, Hazard

\section{Metode}


Penulisan ini dilakukan dengan metode kajian bebas terhadap pokok bahasan yang di kumpulkan dari beberapa sumber yang berkaitan dengan pokok bahasan, seperti jurnal online maupun jurnal print, dan buku online.

Setelah membaca beberapa jurnal dan menyeleksinya penulis menentukan 10 jurnal yang dipilih.

Alasan jurnal yang di pilih diantaranya :

a. Sumbernya jelas

b. Sesuai dengan topik yang diinginkan

c. Batas tahun diterbitkannya artikel tidak lebih dari 10 tahun

\section{Hasil}

Dari penelitian Novie E. Mauliku tahun 2011, risiko bahaya dalam kegiatan rumah sakit dalam aspek kesehatan kerja, antara lain berasal dari sarana kegiatan di poliklinik, ruang perawatan, laboratorium, kamar rontgent, instalasi gizi, laundry, ruang medical record, bagian rumah tangga (housekeeping), farmasi, sterilisasi alat-alat kedokteran, pesawat uap atau bejana dengan tekanan, instalasi peralatan listrik, instalasi proteksi kebakaran, air limbah, sampah medis, dan sebagainya.

Penelitian lain menunjukkan bahwa pekerja kesehatan berisiko terpapar darah dan cairan tubuh yang terinfeksi (bloodborne pathogen) yang dapat menimbulkan infeksi HBV, HCV dan HIV melalui berbagai cara, salah satunya melalui luka tusuk jarum atau benda tajam lainnya.12 Penelitian ini bertujuan untuk mengetahui manajemen risiko K3 menggunakan Hazard Identification Risk Assessment And Risk Control (HIRARC).

Peraturan Pemerintah Republik Indonesia Nomor 33 Tahun 2007 tentang keselamatan radiasi pengion dan keamanan sumber radioaktif, yang bertujuan menjamin keselamatan pekerja dan anggota masyarakat, perlindungan terhadap lingkungan hidup, dan keamanan sumber radioaktif. Diperlukan upaya perlindungan terhadap kesehatan dan keselamatan kerja bagi pekerja di unit radiologi. Rumah Sakit sebagai tempat kerja tidak terlepas dari kecelakaan kerja yang mungkin terjadi. Heinrich (1980) memperkirakan (85\%) kecelakaan adalah hasil kontribusi perilaku kerja yang tidak aman (unsafe act). Kecelakaan radiasi yang dilaporkan oleh United 
State Energy Atomic Commision dari tahun 1960-1968 disebakan oeh kesalahan operator (68\%), kesalahan prosedur (8\%), kerusakan perlengkapan (15\%) dan lain-lain (9\%). Bila dilihat secara rinci kesalahan operator yaitu tidak melakukan survey radiasi (46\%), tidak mengikuti prosedur (36\%), tidak menggunakan peralatan proteksi (6\%), kesalahan manusiawi (6\%), dan kesalahan menghitung paparan radiasi $(6 \%)$. Berdasarkan hal tersebut, menunjukkan hubungan antara perilaku tidak aman (unsafe behavior) dengan cedera (injury) dan menyiratkan bahwa pendekatan pro-aktif untuk pencegahan cedera membutuhkan perhatian terhadap perilaku dan near miss. Putri (2009), melakukan penelitian tentang penggunaan alat proteksi radiasi di ruang pemeriksaan Instalasi Radiodiagnostik RSUD Dr. Soetomo Surabaya dan didapatkan hasil bahwa penggunaan alat proteksi masih sering terabaikan, seperti penggunaan apron pelindung, kacamata pelindung, sarung tangan serta film badge.

\section{Pembahasan}

Perawat merupakan petugas kesehatan dengan presentasi terbesar dan memegang peranan penting dalam pemberian pelayanan kesehatan. WHO (2013) mencatat, dari 39,47 juta petugas kesehatan di seluruh dunia, 66,7\%-nya adalah perawat. Di Indonesia, perawat juga merupakan bagian terbesar dari tenaga kesehatan yang bertugas di rumah sakit yaitu sekitar 47,08\% dan paling banyak berinteraksi dengan pasien (Depkes RI, 2014). Ada sekitar dua puluh tindakan keperawatan, delegasi, dan mandat yang dilakukan dan yang mempunyai potensi bahaya biologis, mekanik, ergonomik, dan fisik terutama pada pekerjaan mengangkat pasien, melakukan injeksi, menjahit luka, pemasangan infus, mengambil sampel darah, dan memasang kateter. Hasil penelitian di beberapa negara membuktikan bahwa rumah sakit adalah salah satu tempat kerja yang berbahaya dan perawat adalah salah satu petugas kesehatan yang berisiko untuk mengalami gangguan kesehatan dan keselamatan kerja akibat dari pekerjaannya.

Sebagai gambaran, biro statistik ketenagakerjaan dan Konsil Nasional Asuransi Amerika (2013) menyimpulkan pada rumah sakit di Amerika setiap 100 jam kerja terjadi 6,8 kejadian kecelakaan kerja dan penyakit akibat kerja (PAK). Angka ini menempatkan kecelakaan kerja dan PAK di rumah sakit sedikit lebih tinggi dibanding dengan kecelakaan kerja dan PAK di sektor lainnya, seperti sektor konstruksi, manufaktur, dan pelayanan profesional dan bisnis lainnya. Sebanyak $48 \%$ kecelakaan kerja disebabkan karena penggunaan tenaga/otot yang berlebihan oleh 
perawat ketika menangani pasien, seperti mengangkat, memindahkan atau menjangkau pasien, dan peralatan medis lainnya.

Perkembangan ilmu pengetahuan di dunia kesehatan memungkinkan pemanfaatan sinar radiasi untuk menegakkan diagnosis penyakit. Radiasi dapat menimbulkan efek buruk bila terpapar secara berlebihan, oleh karena itumanajemen harus dapat menciptakan safe behavior pada radiografer sebagai upaya pencegahan kecelakaan kerja. Manajemen dapat menerapkan behavior based safety dengan mengupayakan intervensi perilaku serta menciptakan faktor eksternal yang mendukung safe behavior radiografer

Faktor yang menjadi kunci keberhasilan Rumah Sakit yaitu dalam menyediakan jasa pengobatan sangat ditentukan oleh kemampuan, kualitas kerja, atau tim medis yang menangani pasien dan kinerja mereka sendiri. Sedangkan salah satu faktor yang dapat mempengaruhi kinerja yaitu budaya Keselamatan Kerja. Budaya Keselamatan Kerja merupakan sikap dalam organisasi dan individu yang menekankan arti dan pentingnya keselamatan. Budaya keselamatan mempersyaratkan agar semua kewajiban yang berkaitan dengan Keselamatan harus dilaksanakan secara benar, seksama, dan dengan rasa tanggung jawab (Yusri,2011).

Budaya Keselamatan adalah paduan sifat dari sikap organisasi dan individu dalam organisasi yang memberikan perhatian dan prioritas utama pada masalah-masalah Keselamatan Radiasi. Paparan Radiasi adalah penyinaran Radiasi yang diterima oleh manusia atau materi, baik disengaja atau tidak, yang berasal dari Radiasi interna maupun eksterna.

Pemeriksaan kesehatan terhadap pekerja yang mungkin terkena paparan radiasi selama melaksanakan tugas tertentu yang terkait dengan radiasi dilaksanakan berdasarkan prinsip umum pengobatan kesehatan kerja. Pemeriksaan kesehatan dilaksanakan sebelum pekerjaan yang menggunakan radiasi dimulai, dan pemeriksaan secara berkala selama bekerja.

a. Pemeriksaan kesehatan awal sebelum bekerja dilaksanakan untuk menilai kesehatan pekerja dan kesesuaiannya untuk melaksanakan pekerjaan yang ditugaskan padanya, dan 
juga untuk mengidentifikasi pekerja mana yang memiliki kondisi yang mungkin memerlukan tindakan keselamatan selama bekerja.

b. Pemeriksaan kesehatan selama bekerja secara berkala dimaksudkan untuk memastikan bahwa tidak ada kondisi klinik yang dapat mempengaruhi kesehatan pekerja yang timbul pada saat bekerja dengan radiasi. Sifat pemeriksaan berkala ini juga didasarkan pada tipe pekerjaan yang dilaksanakan, umur dan status kesehatan, dan perilaku kesehatan pekerja. Rentang waktu pelaksanaan pemeriksaan kesehatan seperti ini umumnya sama frekuensinya dengan program pemantauan kesehatan lainnya. Selain itu, frekuensi pemeriksaan kesehatan didasarkan pada kondisi kesehatan dan tipe pekerjaan. Jika karakter pekerjaan menimbulkan potensi kerusakan kulit karena radiasi, terutama di tangan, maka daerah kulit diperiksa secara berkala.

c. Pemeriksaan kesehatan pada saat akan memutuskan hubungan kerja dimaksudkan untuk mengetahui kondisi kesehatan terakhir pekerja, yang dapat digunakan sebagai bukti yuridis atau rujukan kesehatan untuk melaksanakan pekerjaan yang terkait dengan radiasi selanjutnya.

Radiologi merupakan unit kerja yang memanfaatkan sinar radiasi. Teori Loss Causation Model menggambarkan bahwa loss terjadi apabila terdapat kontak dengan energi (Bird dan Germain, 1992). Perbuatan tidak aman dan kondisi tidak aman menjadi penyebab langsung terjadinya kontak dengan energi radiasi. Berdasarkan hasil penelitian dapat diketahui perilaku tidak aman yang dilakukan radiografer adalah tidak menyalakan lampu indikator ketika pemeriksaan berlangsung. Lampu indikator merupakan tanda bahwa penyinaran dengan radiasi sedang berlangsung. Dengan tidak menyalakan lampu indikator berarti bahwa radiografer gagal mengamankan dan mengingatkan masyarakat bahwa di dalam ruangan tersebut proses penyinaran dengan radiasi sedang berlangsung.

Lawrence Green dan kawan-kawan (1980), menyatakan bahwa perilaku manusia dapat dibentuk oleh 3 faktor yaitu factor predisposisi (predisposing factors), factor pendukung (enabling factors), serta factor pendorong (reinforcing factors). Faktor pendukung (enabling factors) adalah kemampuan dari sumber daya yang diperlukan untuk membentuk perilaku. Penyediaan lampu indikator di setiap ruang pemeriksaan merupakan salah satu bentuk dari factor pendukung perilaku. Dapat dikatakan bahwa tidak tersedianya lampu indikator membentuk perilaku tidak aman radiografer. Pemberian lampu indikator merupakan salah satu standar yang 
harus dipenuhi oleh instalasi radiodiagnostik Rumah Sakit Dr. Soetomo Surabaya sebagai penyedia layanan radiodiagnostik.

Keputusan Menteri Kesehatan Republik Indonesia nomor 1014/MENKES/SK/XI/2008 tentang Standar Pelayanan Radiologi Diagnostik di Sarana Pelayanan Kesehatan menyatakan bahwa di atas pintu masuk ruang pemeriksaan dipasang lampu merah yang menyala pada saat pesawat dihidupkan sebagai tanda sedang dilakukan penyinaran. Lampu indikator merupakan salah satu usaha proteksi radiasi terhadap masyarakat. Setiap tenaga kerja di instalasi atau unit pelayanan radiologi diagnostic mempunyai tugas dan tanggung jawab terhadap semua kegiatan yang berhubungan dengan mutu teknis dan proteksi atau keamanan pelayanan radiodiagnostikimejing atau intervensional (KMK no 1014, 2008).

Potensi bahaya fisika yang teridentifikasi yaitu pencahayaan, dengan melakukan perawatan terhadap pasien pada siang hari. Dapat terjadi resiko bahaya kelelahan mata, keluhan pegal dan efisiensi kerja menurun. Dari peraturan Kepmenkes RI No 1204/MENKES/SK/X/2004 tentang persyaratan kesehatan lingkungan rumah sakit, pencahayaan ruang pasien 100-200 lux dengan warna cahaya sedang. Upaya pengendalian bahaya fisika (pencahayaan) yaitu aktivitas kerja melakukan perawatan terhadap pasien pada siang hari adalah memperoleh penerangan yang cukup dan sesuai.

Langkah-langkah untuk mendapatkan usulan pencegahan faktor bahaya dibagi menjadi 10 tahapan sebegai berikut: identikasi hazard dan penentuan spesifikasi hazard, penyusunan struktur hirarki masalah, pengujian konsistensi matrik berpasangan, penentuan bobot konsensus kategori hazard, perhitungan bobot global, perhitungan bobot konversi, perhitungan frekuensi hazard, perhitungan performansi tingkat bahaya, penyusunan prioritas, dan perumusan usulan pencegahan.

Hasil dari identifikasi bahaya didapatkan lima kategori hazard yang terdapat di Rumah Sakit yaitu biological hazard, chemical hazard, pshycal hazard, pshychological hazard dan environmental and mechanical/ biomechanical hazard. Dari hasil perhitungan, diperoleh nilai hazard yang paling rendah yaitu pshychological hazard dengan nilai 3,991 diikuti dengan biological hazard dengan nilai 4,113, chemical hazard 4,309, environmental and mechanical/ biomechanical hazard 4,396 dan yang paling tinggi pshycal hazard 4,578. Untuk usulan pencegahan diambil hazard dengan nilai paling rendah adalah pshychological hazard dengan nilai 3,991 karena semakin rendah nilai tingkat suatu kinerja semakin buruk. Dari hasil usulan 
pencegahan, beberapa hal yang perlu diperhatikan Rumah Sakit yaitu kuantitas perawat, kualitas perawat dan sistem kerja pada Rumah Sakit.

\section{Penutup}

\section{Kesimpulan}

Keselamatan dan Kesehatan Kerja di Rumah Sakit (K3RS) yaitu segala kegiatan untuk menjamin dan melindungi keselamatan dan kesehatan bagi sumber daya manusia rumah sakit, pasien, pendamping pasien, pengunjung, maupun lingkungan rumah sakit melalui upaya pencegahan kecelakan kerja dan penyakit akibat kerja di rumah sakit.

\section{Saran}

Upaya yang dapat dilakukan oleh perawat untuk meminimalisirkan resiko/hazard yang akan terjad, seperti

a) Batasi akses ke tempat isolasi

b) Menggunakan Alat Pelindung Diri ( APD) dengan benar

c) SOP memasang APD, jangan ada sedikitpun bagian tubuh yang tidak tertutup dengan APD

d) Petugas diharapkan untuk tidak menyentuh bagian tubuh yang tidak tert utup APD

e) Membatasi sentuhan langsung ke pasien

f) Cuci tangan sebelum melakukan dan setelak melakukan tindakan

g) Bersihkan kaki/tangan setelah melakukan tindakan

h) Melakukan pemeriksaan secara berkala kepada perawat/pekerja

i) Hindari memegang benda yang mungkin terkontaminasi

\section{Daftar Pustaka}

1. Handayani, Luh, Titi. (2017) . Analisis Jalur Keselamatan dan Kesehatan Kerja dengan Kepuasan terhadap Kinerja Perawat dalam Memberikan Asuhan Keperawatan di RS Jember. The Indonesian Journal of Health Science, 9(1).

2. Iftadi, Irwan., Jauhari, Wakhid, Ahmad ., Fatmasari, Agarika. (2011) . Penentuan Faktor-Faktor Bahaya yang Dihadapi Perawat di RSUD Kabupaten Karanganyar dan Usulan Pencegahannya Menggunakan Metode AHP. Performa, 10(1).

3. Indragiri, Suzana. (2018) . Manajemen Risiko K3 Menggunakan Hazard Identification Risk Assessment and Risk Control (Hirarc). Jurnal Kesehatan, 9(1).

4. Kumayas, Putri, Elshadai., Kawatu, Paul, A.T., Warouw, Finny. (2019) . Hubungan Pengetahuan dan Sikap Dengan Penerapan Kesehatan dan Keselamatan Kerja (K3) Pada Perawat di Rumah Sakit Bhayangkara TK III Manado. Jurnal KESMAS, 8(7).

5. Pertiwi., Nurhantari, Yudha., Budihardjo, Santosa. (2019) . Hazard Identification, Risk Assesment dan Risk Control serta Penarap Risk Mapping pada Rumah Sakit Hewan 
Prof.Soeparwi Universitas Gajah Mada. Berita Kedokteran Masyarakat (BKM Journal of Community Medicine and Public Health, 35(2).

6. PERATURAN PEMERINTAH REPUBLIK INDONESIA NOMOR 33 TAHUN 2007 TENTANG KESELAMATAN RADIASI PENGION DAN KEAMANAN SUMBER RADIOAKTIF

7. Putri, Sentya., Santoso., Rahayu, Endang, Purnawati. (2018) . Pelaksanaan Keselamatan dan Kesehatan Kerja Terhadap Kejadian Kecelakaan Kerja Perawat Rumah Sakit. Jurnal Endurance, 3(2).

8. Rahmawati, Neni., Martiana, Tri. (2014) . Analisis Safe Behavior dengan Pendekatan BehaviorBased pada Radiografer di Rumah Sakit Dr. Soetomo Surabaya. The Indonesian Journal of Occupational Safety, Health and Environment, 1(1).

9. Ramdan, Iwan, M., Rahman, Abd. (2017) . Analisis Risiko Kesehatan dan Keselamatan Kerja (K3) pada Perawat. JKP, 5(3).

10. Romadhoni,Sutianik., Widowati, Evi. (2017) . Penerapan Kewaspadaan Standar Sebagai Upaya Pencegahan Bahaya Biologi pada Tenaga Keperawatan. Higeia Journal Of Public Health Research and Development, 4(1).

11. Simamora, R. H. (2019). Pengaruh Penyuluhan Identifikasi Pasien dengan Menggunakan Media Audiovisual terhadap Pengetahuan Pasien Rawat Inap. Jurnal Keperawatan Silampari, 3(1), 342-351.

12. Simamora, R. H. (2020). Learning of Patient Identification in Patient Safety Programs Through Clinical Preceptor Models. Medico Legal Update, 20(3), 553-556. 